\title{
Cutaneous Mantle Cell Lymphoma
}

National Cancer Institute

\section{Source}

National Cancer Institute. Cutaneous Mantle Cell Lymphoma. NCI Thesaurus. Code C45266.

Mantle cell lymphoma that affects the skin. 